\title{
High diversity and abundance of scleractinian corals growing on and near mangrove prop roots, St. John, US Virgin Islands
}

Received: 20 April 2009/Accepted: 10 June 2009/Published online: 12 July 2009

(C) Springer-Verlag 2009
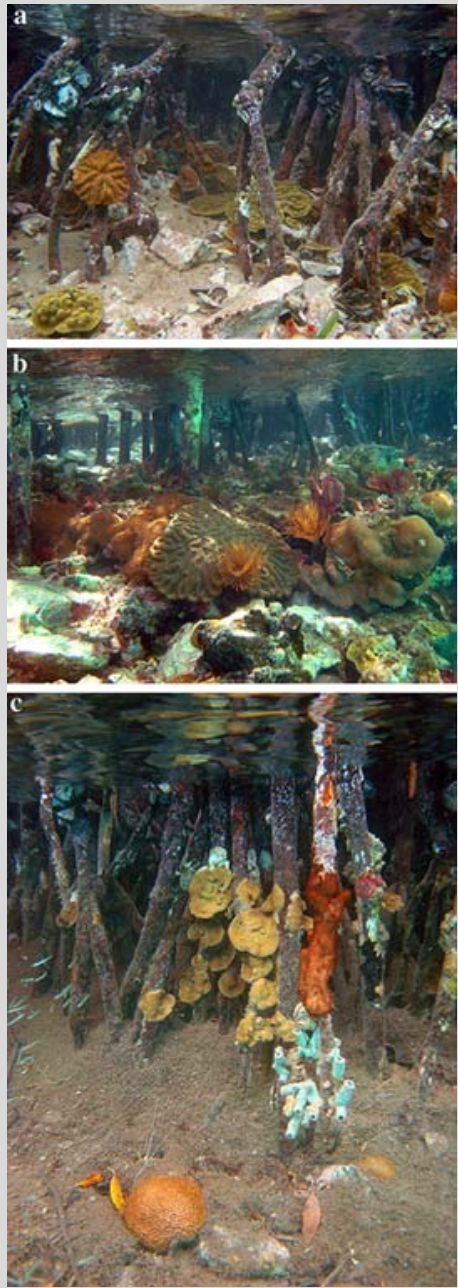

Fig. 1 Several species of corals growing directly on or near the prop roots of red mangrove trees: a $C$. natans, Agaricia spp., and $P$. astreoides, $\mathbf{b}$ large colonies of $M$. faveolata and $C$. natans, c $S$. siderea (foreground) and Agaricia spp. on prop roots
A narrow zone of red mangroves fringes the shorelines of four small bays in Hurricane Hole, within Virgin Islands Coral Reef National Monument (VICRNM) on St. John. In two of these bays, Otter Creek and Water Creek, a particularly high abundance and diversity of corals are growing directly on or near the prop roots (Fig. 1a,b,c). To date, 28 coral species have been found: Stephanocoenia intersepta, Agaricia sp., Agaricia agaricites, Siderastrea siderea, S. radians, Porites porites, P. astreoides, $P$. furcata, $P$. divaricata, Favia fragum, Diploria strigosa, D. labyrinthiformis, D. clivosa, Manicina areolata, Colpophyllia natans, C. amaranthus, Montastraea annularis, M. faveolata, M. franksi, M. cavernosa, Oculina diffusa, Meandrina meandrites, Dendrogyra cylindrus, Scolymia cubensis, Mycetophyllia sp., Eusmilia fastigiata, Cladocora arbuscula, and Tubastrea coccinea. The size of many of the colonies, including some $M$. faveolata and C. natans colonies over $1 \mathrm{~m}$ across (Fig. 1b), indicate that they survived the $2005 / 2006$ bleaching and disease event that caused losses of over $60 \%$ of the coral cover on St. John reefs (Rogers et al. 2008). Shading by the mangroves possibly reduced the thermal and photic stress on these corals. The coral diversity in these mangroves may be higher than for other Caribbean mangrove systems. Few published papers include data on corals in these habitats. Two comprehensive reviews of the biology of mangroves make no reference to corals on or near prop roots (Kathiresan and Bingham 2001; Nagelkerken et al. 2008). The number of corals in Hurricane Hole, particularly the new recruits on the prop roots (Fig. 1c), may have increased since the establishment of the VICRNM in 2001, as boaters are not permitted to overnight in these bays or to tie their boats to the mangrove trees as was done in the past.

Acknowledgments Thanks to J. Miller, R. Boulon, E. Weil and J. Lang for lively discussions about the corals in these bays, and to K. and R. Vahling for research support.

\section{References}

Kathiresan K, Bingham BL (2001) Biology of mangroves and mangrove ecosystems. Adv Mar Biol 40:81-251

Nagelkerken I, Blaber S, Bouillon S, Green P, Haywood M, Kirton L, Meynecke J-O, Pawlik J, Penrose H, Sasekumar A, Somerfield P (2008) The habitat function of mangroves for terrestrial and marine fauna: a review. Aquat Bot 89:155-185

Rogers CS, Miller J, Muller EM (2008) Coral diseases following massive bleaching in 2005 cause 60 percent decline in coral cover and mortality of the threatened species, Acropora palmata, on reefs in the US Virgin Islands. USGS Fact Sheet 2008-3058

\section{S. Rogers (ه)}

US Geological Survey, Florida Integrated Science Center, Caribbean Field Station, 1300 Cruz Bay Creek, St. John, USVI 00830, USA e-mail: caroline_rogers@usgs.gov

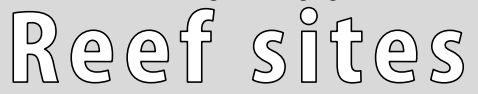

Coral Reefs (2009) 28:909 DOI $10.1007 / \mathrm{s} 00338-009-0526-4$ 